\title{
DIATOMS OF TEMPORARY AND PERMANENT WATERCOURSES IN SOUTHERN EUROPE (PORTUGAL)
}

\author{
M. H. NOVAIS ${ }^{\mathrm{a}, \mathrm{b} *}$, M. M. MORAIS ${ }^{\mathrm{a}}$, J. ROSADO ${ }^{\mathrm{a}}$, L. S. DIAS ${ }^{\mathrm{c}}$, L. HOFFMANN ${ }^{\mathrm{b}}$ AND L. ECTOR $^{\mathrm{b}}$ \\ ${ }^{a}$ Laboratório da Água, Centro de Geofísica da Universidade de Évora, Évora, Portugal \\ b Public Research Centre-Gabriel Lippmann, Department of Environment and Agro-biotechnologies, Belvaux, Luxembourg \\ ${ }^{\mathrm{c}}$ Departamento de Biologia, Universidade de Évora, Évora, Portugal
}

\begin{abstract}
The potential importance of benthic diatoms in Mediterranean watercourses has received limited academic attention historically. This study sought to provide baseline information for this poorly studied group. Temporary and permanent watercourses in Portugal differ in catchment characteristics, climatic variables and water chemistry. The benthic diatom communities were characterized in terms of ecological preferences and conservation status for taxa with relative abundance above 1\% in at least one site covering 39 temporary sites (109 taxa) and 53 permanent sites (130 taxa). The low-profile guild dominated both temporary and permanent watercourses, followed by the high-profile and motile guilds. Indicator value analysis indicated that Amphora copulata, Cocconeis placentula, Diploneis separanda, Encyonopsis subminuta, Fragilaria radians, Gomphonema olivaceum, Gomphonema truncatum, Halamphora veneta, Navicula radiosa, Navicula veneta, Sellaphora seminulum and Ulnaria acus were indicators of temporary watercourses, whereas Encyonema minutum, Eunotia minor, Fragilaria rumpens, Fragilaria cf. socia and Navicula rhynchocephala were characteristic of permanent watercourses. Ecological preferences of indicator taxa were inferred on the basis of environmental variables that differed significantly between temporary and permanent watercourses. The importance of temporary watercourses for the maintenance of diatom biodiversity is discussed and explored. Copyright (C) 2014 John Wiley \& Sons, Ltd.
\end{abstract}

KEY WORDS: diatoms; ecological guilds; ecological preferences; indicator taxa; seasonality

Received 19 November 2013; Revised 11 July 2014; Accepted 14 July 2014

\section{INTRODUCTION}

Rivers that periodically cease to flow comprise a substantial proportion of the total number, length and discharge of the world's rivers (Tooth, 2000). Temporary rivers are not restricted to arid regions; they occur in most terrestrial biomes between $84^{\circ} \mathrm{N}$ and $\mathrm{S}$ latitudes (Larned et al., 2010). During the next century, the number and length of rivers that become temporary may increase in regions experiencing drying trends as a result of climate change and water abstraction for socio-economic uses (Rosado et al., 2012). An increase of $50 \%$ in the use of water for agriculture and industry is also predicted by 2025 (Tockner and Stanford, 2002). Furthermore, it is assumed that climate change will result in significant aquatic biodiversity losses due to changes in population dynamics resulting from an increasingly harsh environment.

The Mediterranean Region is predicted to experience greater flood frequency, punctuated by warmer, drier conditions that will lead to more frequent and prolonged droughts

\footnotetext{
*Correspondence to: M. H. Novais, Laboratório da Água, Centro de Geofísica da Universidade de Évora, Parque Industrial e Tecnológico, P-7005-345 Évora, Portugal.

E-mail: novaismh@gmail.com
}

during the summer months, on the basis of most climate change models (Barceló and Sabater, 2010; IPCC, 2014) and represents a prominent 'hot spot' for potential change in water availability (Giorgi and Lionello, 2008). In Portugal, for instance, current estimates indicate that the total surface area drained by temporary rivers represents more than $80 \%$ of the Portuguese territory. Furthermore, in the south-east of the country, the driest region, the only permanent watercourses are the large rivers Guadiana, Sado and Mira, and $\sim 90 \%$ of watercourses are temporary in character (Morais, unpublished data).

The extension and vulnerability of these aquatic systems have led to an increase in research on temporary rivers in the Mediterranean Region (e.g. Morais et al., 2004; Feio et al., 2010; Dodkins et al., 2012). Nevertheless, phytobenthos has generally been overlooked in temporary rivers, and until recently, research undertaken on the use of diatoms as indicators of ecological status in Mediterranean temporary streams (e.g. diatom metrics and indices) has been limited (e.g. Martín et al., 2010; Delgado et al., 2012).

Despite the importance of temporary rivers in the Mediterranean region, the European Union Water Framework Directive (Directive 2000/60/EC) does not explicitly recognize their value or importance, probably because intermittency 
is a naturally occurring phenomena. Nevertheless, the effects of a temporary flow regime and measures to address this (where appropriate) should be included in any update of river basin management plans. However, to propose appropriate measures, a detailed knowledge of the biotic components of temporary watercourses is crucial.

This topic requires specific attention because the implementation of the Water Framework Directive (Directive 2000/60/EC) requires European countries to assess lotic ecosystem quality using diatoms in addition to other biological elements. Diatoms are considered excellent environmental indicators because they represent a large part of the freshwater algal diversity, occur in almost all aquatic habitats and respond directly to many physical, chemical and biological changes in aquatic ecosystems. Furthermore, the value of diatoms as ecological indicators has been demonstrated in a variety of surface waters, primarily lakes and reservoirs (e.g. Novais et al., 2012). A biological indicator approach based on diatom growth forms, capacity to tolerate nutrient limitation and physical disturbance was proposed by Passy (2007) and is currently being widely tested across Europe (Berthon et al., 2011; Gottschalk and Kahlert, 2012).

The aim of this study is to enhance the baseline knowledge available concerning benthic diatoms in Mediterranean watercourses. The objectives of this research were as follows: (i) to provide an abiotic characterization of watercourses in the South of Portugal; (ii) to characterize benthic diatoms in temporary and permanent watercourses in Southern Portugal by assessing several indicators including ecological guilds, species richness, diversity and conservation status; and (iii) to determine ecological preferences of taxa that are characteristic of temporary and permanent watercourses.

\section{METHODS}

\section{Sampling sites}

A total of 92 sites were sampled in southern and central Portugal during spring 2006, when differences in the flow regime were already apparent but prior to temporary watercourses drying during late spring. The sites comprised 39 temporary and 53 permanent watercourses, according to the hydrological regime determined using a surface runoff model within a geographic information system (INAG, 2008a), and were located within the following watersheds: Ribeiras do Algarve (17), Guadiana (12), Mira and Sado (13) and Tejo (50) (Figure 1). The sites selected were subject to low anthropogenic pressure in accordance with the objectives of the study. The site selection was initially based on the REFCOND (2003) criteria developed by the National Water Institute. The environmental characterization of each site was intended to be comprehensive and addressed watershed characteristics, climatological, hydromorphological and

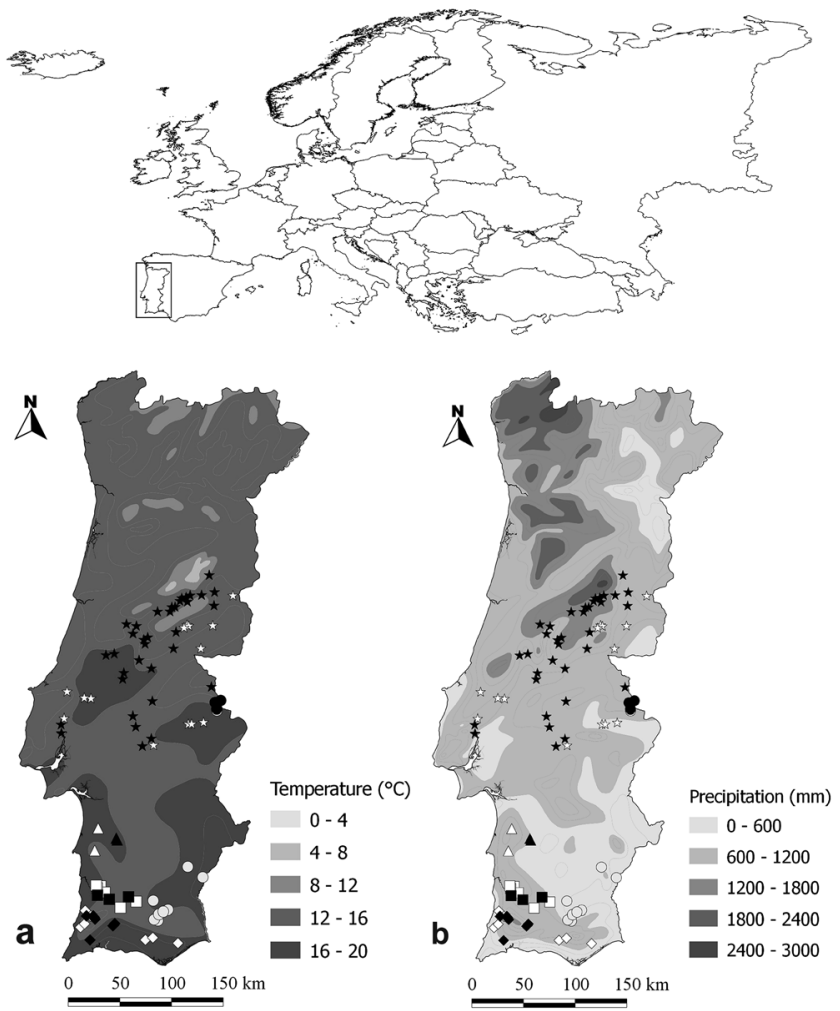

Figure 1. Map of Europe indicating the location of Portugal. Map of Portugal indicating (a) average annual temperature and (b) average annual precipitation (source: Atlas do Ambiente Digital-IA). Symbols on the maps indicate the catchments examined in this study: circle $=$ Guadiana; triangle $=$ Sado; square $=$ Mira; diamond $=$ Ribeiras do Algarve; and $\mathrm{star}=$ Tejo. Solid $/$ black=permanent watercourses and open/white $=$ temporary watercourses

water chemistry parameters. For each site, elevation, catchment area upstream of the sample site, distance to source, average annual runoff, thermal amplitude, coefficient of variation of annual precipitation, and mean annual temperature and precipitation were derived from the National Water Institute database. In addition, land use within the watershed, urban area, presence and characteristics of the riparian vegetation, sediment loads, level of hydromorphological alteration and changes to river connectivity caused by the presence of dams were recorded. The potential effects of toxicity, acidification and organic contamination were identified and explored by collecting water quality samples and analysis of the following parameters: dissolved oxygen $\geq 5 \mathrm{mg} \mathrm{O}_{2} \mathrm{~L}^{-1}$, $6 \leq \mathrm{pH} \leq 9$, ammonium $\leq 1 \mathrm{mg} \mathrm{NH}_{4}^{+} \mathrm{L}^{-1}$, nitrates $\leq 25 \mathrm{mg}$ $\mathrm{NO}_{3}^{-} \mathrm{L}^{-1}$, total phosphorus $\leq 0.13 \mathrm{mg} \mathrm{PL}^{-1}$ and biological oxygen demand $\leq 6 \mathrm{mg} \mathrm{O}_{2} \mathrm{~L}^{-1}$ (INAG, 2009).

Hydromorphological characterization was undertaken simultaneously with diatom community and water quality sample collection; water temperature, $\mathrm{pH}$, oxygen saturation and conductivity were measured in situ with portable meters calibrated in the field. Additional field measurements of 
flow velocity, percentage of channel shaded, channel depth, channel width and wetted width and the presence or absence and type of riparian vegetation were recorded. Environmental standard methods for water chemical analyses were carried out according to APHA (1995), and all variables examined are summarized in Tables I and II.

\section{Diatom sampling and processing}

Benthic epilithic diatoms were sampled following a standard methodology (European Committee for Standardization, 2003; INAG, 2008b), which consisted in brushing at least five wellilluminated stones (cobbles if available) occurring in the main flow under stable conditions. All samples were preserved with a formaldehyde solution $(4 \% \mathrm{v} / \mathrm{v})$ immediately after sampling. Samples were treated using hydrogen peroxide $(35 \%)$ and $\mathrm{HCl}$ $(37 \%)$ in order to obtain a suspension of clean frustules. Permanent slides were mounted with Naphrax ${ }^{\circledR}$ (Brunel Microscopes Ltd, Wiltshire, UK). Diatoms were identified to a specific or sub-specific level using light microscopy (Leica DMRX with 100x oil immersion objective, Leica Microsystems, Wetzlar, Germany). At least 400 valves were identified and counted from each slide to estimate the relative abundance of each taxon. Identification was based on diatom reference floras (e.g. Krammer and Lange-Bertalot, 1986, 1988, 1991a, 1991b), as well as recent bibliographic sources, including the series 'Diatoms of Europe', 'Iconographia Diatomologica', 'Bibliotheca Diatomologica' and relevant taxonomic papers.

\section{Data analysis-environmental variables}

Environmental variables were standardized and log transformed prior to analysis. The Shapiro-Wilk normality test was conducted using SigmaPlot 12.0 (Systat Software Inc., Chicago, IL). To verify which variables differed significantly between temporary and permanent watercourses, the nonparametric Mann-Whitney $U$ test was used. Subsequently, a comparison between climatological, hydromorphological and water chemistry variables was undertaken by means of non-parametric Spearman rank correlations. Both MannWhitney $U$ tests and Spearman rank correlations were undertaken using STATISTICA 6.0 (StatSoft, Inc., Tulsa, OK).

\section{Data analysis-diatoms}

Diatom taxa were characterized in terms of habitat, flow velocity (when flowing), moisture content, $\mathrm{pH}$, trophic state, ecology and conservation status according to the diatom 'Red List' compiled by Lange-Bertalot and Steindorf (1996) for German watercourses (based on Denys, 1991; Van Dam et al., 1994; Lange-Bertalot and Steindorf, 1996) and the 2012 OMNIDIA v. 5.3 (Omnis Software, Inc.) database (Lecointe et al., 1993). Ecological guilds were assigned to all taxa identified following the classification of Passy (2007) and Berthon et al. (2011): low-profile, high-profile and motile guilds. To examine the influence of environmental variables on ecological guilds' relative abundance and to compare information provided by the Specific Pollution Sensitivity Index (SPI) and ecological guilds, Spearman rank correlations were calculated using STATISTICA 6.0 (StatSoft, Inc.).

The indicator value (IndVal) method was used to identify the key species (indicators) of temporary and permanent watercourses (Dufrêne and Legendre, 1997), using PC-Ord 6.0 (MjM Software Ltd., 217-219 Hamstel Road, Southend on Sea Essex SS2 4LB). This provides IndVals for each species, based on the combination of information on the specificity and fidelity of occurrence of a taxon in a group. The statistical significance of the species IndVal was evaluated using Monte Carlo random permutation tests. Ecological preferences of indicator species were inferred on the basis of the environmental variables that differed significantly between temporary and permanent watercourses.

For each sample, taxa richness $(S)$, Shannon index of diversity $\left(H^{\prime}\right)$ and Pielou's evenness index $\left(J^{\prime}\right)$ were determined.

Table I. Catchment and climatological characteristics of the temporary and permanent watercourses examined in the southern Portugal study area

\begin{tabular}{lrrrrr}
\hline & & \multirow{2}{*}{ Temporary } & & \multicolumn{2}{c}{ Permanent } \\
\cline { 2 - 3 } \cline { 5 - 6 } Variable & Median & Interquartile range & & Median & Interquartile range \\
\hline Elevation (m above sea level) & 138.91 & $61.03-214.46$ & & 129.80 & $66.00-342.18$ \\
Catchment area upstream** $\left(\mathrm{km}^{2}\right)$ & 57.34 & $33.32-150.81$ & & 127.36 & $66.36-984.55$ \\
Distance to source** $(\mathrm{m})$ & 18999.26 & $12282.53-28865.43$ & 29920.60 & $16849.90-72644.10$ \\
Average annual runoff* $(\mathrm{mm})$ & 175.00 & $175.00-250.00$ & & 350.00 & $175.00-700.00$ \\
Thermal amplitude $\left({ }^{\circ} \mathrm{C}\right)$ & 10.34 & $9.99-11.30$ & & 10.39 & $9.70-11.23$ \\
Average annual temperature** $\left({ }^{\circ} \mathrm{C}\right)$ & 15.62 & $15.11-15.99$ & & 15.18 & $13.70-15.35$ \\
Average annual precipitation $* *(\mathrm{~mm})$ & 668.00 & $633.75-763.50$ & & 804.00 & $686.00-1042.00$ \\
Coefficient of variation of annual precipitation & 0.31 & $0.29-0.32$ & & 0.30 & $0.29-0.31$ \\
\hline
\end{tabular}

Variables that differ between temporary and permanent watercourses are indicated by

$* p<0.05$ and $* * p<0.001$ using the Mann-Whitney $U$ test. 
Table II. Physical and water chemistry characteristics of the temporary and permanent watercourses examined in the study area.

\begin{tabular}{|c|c|c|c|c|}
\hline \multirow[b]{2}{*}{ Variable } & \multicolumn{2}{|c|}{ Temporary } & \multicolumn{2}{|c|}{ Permanent } \\
\hline & Median & Interquartile range & Median & Interquartile range \\
\hline Current velocity** $\left(\mathrm{m} \mathrm{s}^{-1}\right)$ & 0.32 & $0.00-0.58$ & 0.67 & $0.41-0.91$ \\
\hline Water temperature* $\left({ }^{\circ} \mathrm{C}\right)$ & 19.36 & $15.85-20.94$ & 23.52 & $17.70-26.19$ \\
\hline Conductivity (Cond) $* *\left(\mu \mathrm{S} \mathrm{cm}^{-1}\right)$ & 392.50 & $223.75-586.50$ & 143.00 & $109.00-333.00$ \\
\hline $\mathrm{pH}^{*}$ & 7.49 & $6.94-7.85$ & 7.12 & $6.64-7.48$ \\
\hline Oxygen $\left(\mathrm{O}_{2}\right)^{* *}(\%)$ & 72.95 & $67.78-81.60$ & 84.60 & $73.20-99.20$ \\
\hline Alkalinity** $\left(\mathrm{mg} \mathrm{L}^{-1}\right)$ & 62.50 & $46.50-167.50$ & 40.00 & $34.00-61.00$ \\
\hline Hardness $* *\left(\mathrm{mg} \mathrm{L}^{-1}\right)$ & 96.50 & $51.75-173.50$ & 32.00 & $10.00-85.00$ \\
\hline Phosphate $\left(\mathrm{PO}_{4}^{-3}\right)\left(\mu \mathrm{g} \mathrm{L}^{-1}\right)$ & 24.00 & $11.25-49.00$ & 32.00 & $9.00-52.00$ \\
\hline Total phosphorus (Ptot) $\left(\mu \mathrm{g} \mathrm{L}^{-1}\right)$ & 19.50 & $8.75-29.75$ & 21.00 & $9.00-32.00$ \\
\hline Soluble reactive phosphorus (SRP) $\left(\mu \mathrm{gL}^{-1}\right)$ & 8.00 & $3.75-16.00$ & 10.00 & $3.00-17.00$ \\
\hline Total organic carbon (TOC) $\left(\mathrm{mg} \mathrm{L}^{-1}\right)$ & 2.96 & $1.70-6.13$ & 2.90 & $1.40-4.70$ \\
\hline Chemical oxygen demand (COD) $\left(\mathrm{mg} \mathrm{L}^{-1}\right)$ & 12.00 & $6.00-18.00$ & 9.00 & $4.00-13.00$ \\
\hline Biological oxygen demand $\left(\mathrm{BOD}_{5}\right)\left(\mathrm{mg} \mathrm{L}^{-1}\right)$ & 1.00 & $0.00-4.00$ & 2.00 & $0.00-4.00$ \\
\hline Ammonium $\left(\mathrm{NH}_{4}^{+}\right)\left(\mu \mathrm{g} \mathrm{L}^{-1}\right)$ & 2.00 & $2.00-23.75$ & 2.00 & $2.00-20.00$ \\
\hline Kjeldahl nitrogen $\left(\mu \mathrm{g} \mathrm{L}^{-1}\right)$ & 1120.00 & $560.00-1680.00$ & 1120.00 & $560.00-1120.00$ \\
\hline Nitrate $\left(\mathrm{NO}_{3}^{-}\right)\left(\mu \mathrm{g} \mathrm{L}^{-1}\right)$ & 275.50 & $159.75-487.25$ & 315.00 & $220.00-386.00$ \\
\hline Nitrite $\left(\mathrm{NO}_{2}^{-}\right)\left(\mu \mathrm{g} \mathrm{L}^{-1}\right)$ & 1.00 & $0.00-10.00$ & 10.00 & $0.00-20.00$ \\
\hline Total nitrogen $\left(\mathrm{mg} \mathrm{L}^{-1}\right)$ & 1335.00 & $985.86-1979.00$ & 1355.00 & $898.00-1795.00$ \\
\hline Chloride $\left(\mathrm{Cl}^{-}\right)^{*}\left(\mathrm{mg} \mathrm{L}^{-1}\right)$ & 40.45 & $23.80-88.68$ & 19.40 & $17.40-31.30$ \\
\hline Sulfate $\left(\mathrm{SO}_{4}^{-2}\right)\left(\mathrm{m} \mathrm{L}^{-1}\right)$ & 22.40 & $9.98-29.73$ & 13.60 & $9.33-18.10$ \\
\hline Sodium $\left(\mathrm{Na}^{+}\right)^{*}\left(\mathrm{mg} \mathrm{L}^{-1}\right)$ & 3.70 & $2.33-6.03$ & 2.70 & $1.10-5.20$ \\
\hline Manganese $\left(\mathrm{Mn}^{2+}\right)\left(\mathrm{mg} \mathrm{L}^{-1}\right)$ & 0.01 & $0.01-0.05$ & 0.02 & $0.01-0.08$ \\
\hline Magnesium $\left(\mathrm{Mg}^{2+}\right) *\left(\mathrm{mg} \mathrm{L}^{-1}\right)$ & 8.02 & $4.37-13.55$ & 4.86 & $3.16-7.05$ \\
\hline Calcium $\left(\mathrm{Ca}^{2+}\right)^{*}\left(\mathrm{mg} \mathrm{L}^{-1}\right)$ & 19.50 & $11.25-33.93$ & 12.40 & $8.00-22.00$ \\
\hline
\end{tabular}

Variables that significantly differ between temporary and permanent watercourses are indicated by $* p<0.05$ and $* * p<0.001$ using the Mann-Whitney $U$ test.

The SPI was also calculated from diatom abundances (Coste in Cemagref, 1982), using the OMNIDIA v. 5.3 software (Lecointe et al., 1993). OMNIDIA was selected because it has been developed for assessing the quality of running waters and has been recommended as reference index for several Iberian basins (Gomà et al., 2005; Blanco et al., 2008).

The relationship between taxa richness $(S)$, Shannon index of diversity $\left(H^{\prime}\right)$, Pielou's evenness index $\left(J^{\prime}\right)$, SPI and the 11 environmental variables that varied significantly between temporary and permanent watercourses was investigated by least squares stepwise multiple linear regression with experiment-wise type I error rates of 0.05 for coefficients calculated using the Dunn-Šidák method (Ury, 1976). The complete candidate model included one qualitative variable, namely the watercourse regime (which was binary coded as 0 or 1), 11 environmental variables and all interactions between watercourse regime and environmental variables. Variance inflation factors and Durbin-Watson $d$ were examined to evaluate multicollinearity and serial correlation. Equations were fitted using Statgraphics 4.2 (STCS, Inc., Rockville, MD). Only taxa with relative abundances over $1 \%$ from at least one site were considered in the analyses in order to reduce the influence of rare taxa.

\section{RESULTS}

Environmental characterization of temporary and permanent streams

Descriptive statistics of the environmental parameters recorded from the temporary and permanent watercourses are presented in Tables I and II. On the basis of the MannWhitney $U$ test, temporary and permanent watercourses differ in catchment characteristics $(p<0.001)$, climatological variables (average annual temperature and precipitation, both $p<0.001$, and average annual runoff, $p<0.05$ ), current velocity $(p<0.001)$ and several water chemistry variables (Table II). A detailed examination of the data indicated that catchment area upstream of the sample point, distance to source, average annual precipitation, average annual runoff, current velocity, dissolved oxygen saturation and water temperature were higher in permanent watercourses. In contrast, average annual temperature, conductivity, alkalinity, hardness, $\mathrm{pH}$, chloride, magnesium, sodium and calcium were higher in temporary watercourses.

The application of the Mann-Whitney $U$ test to the hydromorphological variables only detected significant differences for water current between the two groups (with 
$p<0.001$; Table II). Because statistical differences were not observed for other hydromorphological variables, a series of charts were plotted to explore the variability of hydromorphological parameters among the groups (Figure 2). Temporary watercourses were typically less shaded, with a greater proportion of sites with no shade or $<30 \%$ of the river channel shaded. Temporary and permanent watercourses had similar proportions of sites $>60 \%$ shaded, and there was a higher percentage of permanent sites with $30-60 \%$ of the channel shaded. These results were reinforced by examination of the type of riparian vegetation (Figure 2e). Temporary watercourses were generally narrower and had smaller channels, as illustrated by a higher percentage of low-river-width (between 1-5 and 5-10 m) and lower-channel-width $(<1 \mathrm{~m})$ sites. Permanent sites had a greater percentage of sites that were $>20 \mathrm{~m}$ wide (Figure $2 \mathrm{~b}, \mathrm{c}$ ), although they also had relatively high proportions of sites with low channel width (1-5 m being the most common). Both temporary and permanent watercourses had high percentages of shallow sites $(<0.25 \mathrm{~m})$; temporary systems were dominated by the $0.25-$ to $0.5-\mathrm{m}$ depth class and permanent rivers by the 0.5 - to 1 - and $>1-\mathrm{m}$ classes. The absence of sites in temporary watercourses with $>1$-m depth is noticeable (Figure 2d).

Climatological variables were clearly different between groups with temporary watercourses typically located in areas with higher average annual temperature and lower average annual runoff and annual precipitation (Table I and Figure 1). In the south-east of the country, the driest region, the majority of watercourses were temporary (Figure 1), whereas precipitation and average annual runoff were higher and more variable in permanent watercourses typical of the central region (Table I and Figure 1).

Spearman correlation coefficients between catchment characteristics and climatological and hydromorphological variables indicated that elevation was positively correlated $(p<0.001)$ with climatological variables including average annual runoff $(r=0.56)$ and average annual precipitation $(r=0.53)$. Elevation was also negatively correlated with the average annual temperature $(r=-0.59)$. Catchment area and distance to source were strongly correlated $(p<0.001)$
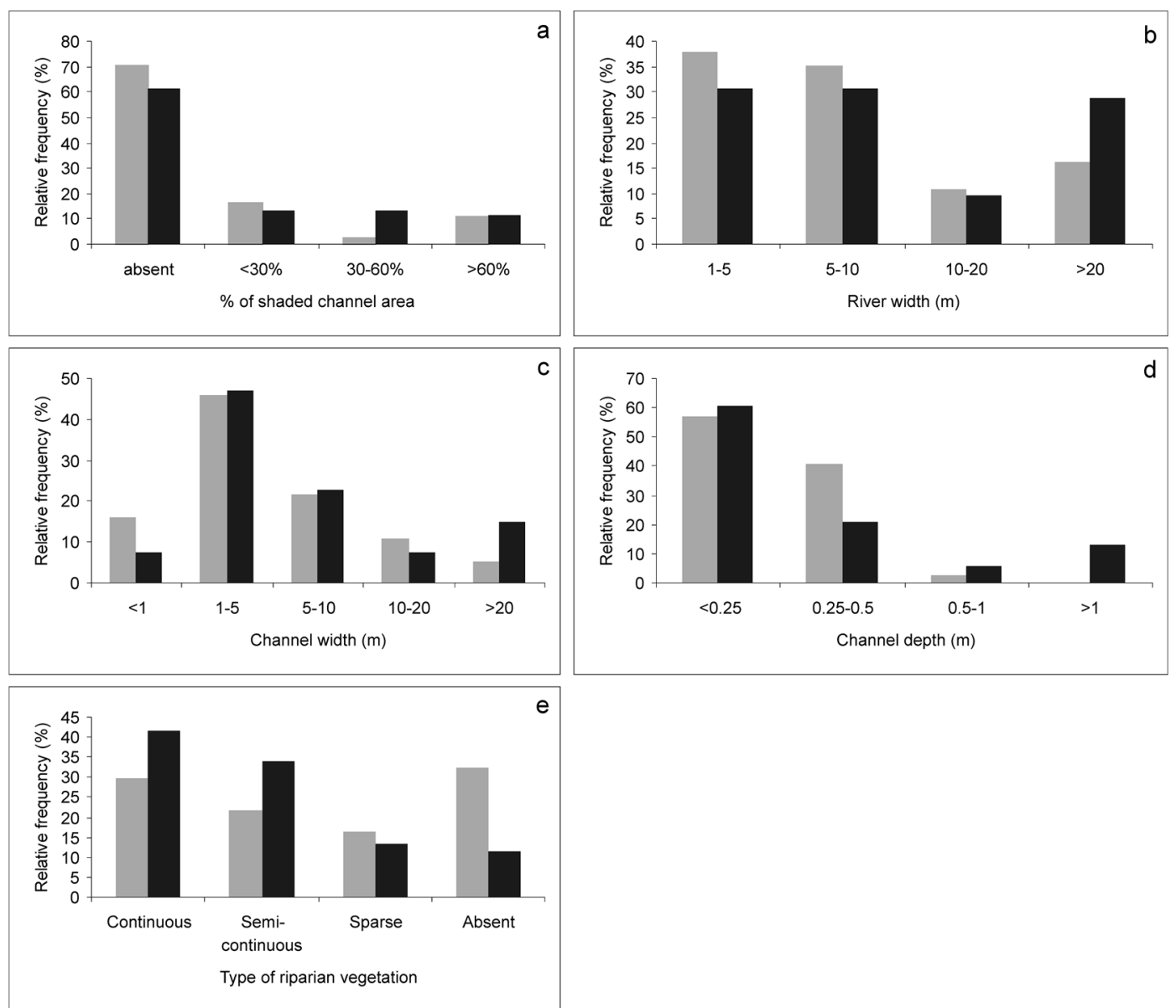

Figure 2. Comparison of mean values of characteristics of temporary (grey) and permanent (black) watercourses within the study area expressed as frequencies for: (a) percentage of channel area shaded; (b) river width; (c) channel width; (d) channel depth; and (e) type of riparian vegetation 
with hydromorphological variables such as river width ( $r=0.56$ and $r=0.61$, respectively) and channel width ( $r=0.48$ and $r=0.56$, respectively).

The Spearman correlations between catchment characteristics, climatological and hydromorphological variables and water chemistry were used to explore the contribution of each of these variables to the changes in water chemistry observed. The only catchment characteristic correlated with water chemistry was elevation, which is negatively correlated $(p<0.001)$ with conductivity $(r=-0.61)$, calcium $(r=-0.57)$, chloride $(r=-0.62)$, hardness $(r=-0.56)$ and sodium $(r=-0.52)$. For the climatological variables, negative correlations $(p<0.001)$ were observed between the average annual runoff and conductivity $(r=-0.55)$, alkalinity $(r=-0.52)$, calcium $(r=-0.57)$, chloride $(r=-0.63)$, hardness $(r=-0.55)$ and magnesium $(r=-0.49)$. Average annual precipitation was negatively correlated $(p<0.001)$ with conductivity $(r=-0.50)$, chloride $(r=-0.56)$, chemical oxygen demand $(r=-0.50)$ and hardness $(r=-0.52)$ and positively correlated with water temperature $(r=0.50)$ and nitrite $(r=0.53)$. It was interesting to note that neither riparian vegetation nor current velocity was correlated with any water chemistry parameters.

\section{Diatom communities' characterization}

A total of 322 diatom taxa were identified in the dataset; from these, 229 were recorded in temporary watercourses and 250 from permanent systems. Only 109 taxa were present with a relative abundance above $1 \%$ from at least one temporary watercourse and 130 taxa from permanent water bodies. Within temporary watercourses, taxa with relative abundance above 1\% comprised 34 genera: Gomphonema (15 taxa) and Achnanthidium (11 taxa); and from perennial flowing sites, the most frequently sampled genera comprised Achnanthidium (16 taxa), Fragilaria (14 taxa), Gomphonema (13 taxa), Nitzschia (14 taxa) and Navicula (13 taxa). Appendix A includes the taxa with relative abundances above $1 \%$ from at least one site, their ecological preferences and conservation status (based on published literature), maximum relative abundance and frequency of occurrence within each group. Achnanthidium minutissimum, Amphora pediculus, Cocconeis euglypta, Gomphonema rosenstockianum, Planothidium frequentissimum, Nitzschia inconspicua and Reimeria sinuata were among the most abundant taxa and occurred at more than $50 \%$ of sites in temporary watercourses. Within permanent watercourses, the most abundant and frequently recorded taxa were A. minutissimum, Eolimna minima, Karayevia oblongella, $P$. frequentissimum and $R$. sinuata.

The Red List status (Lange-Bertalot and Steindorf, 1996) was available for $\sim 70 \%$ of the taxa (Appendix A). From these, $\sim 12.5 \%$ are classified as endangered to varying degrees. Among the diatoms recorded, Achnanthidium lineare and Stauroforma exiguiformis have been classified as 'endangered' (category 3); S. exiguiformis only occurs in permanent watercourses, whereas A.lineare also occurs in temporary waterbodies infrequently. Gomphonema lagenula and Navicula cataracta-rheni are classified as 'extremely rare' (R). Gomphonema lagenula was found in low abundances in both temporary and permanent watercourses, whereas $N$. cataracta-rheni was typically present in low abundance within temporary watercourses. Achnanthidium subatomoides, Fragilaria nanana, Gomphonema exilissimum, Karayevia oblongella and Pinnularia microstauron are classified as 'decreasing' (V). Among these taxa, G. exilissimum and $K$. oblongella were present in more than $10 \%$ of both temporary and permanent watercourses, and K. oblongella was also abundant in both groups ( $>40 \%$ maximum relative abundance). In contrast, A. subatomoides, $F$. nanana and $P$. microstauron were only recorded from permanent watercourses in low abundances. For Eunotia implicata, Eunotia soleirolii, Navicula notha and Ulnaria biceps, threats to their long-term conservation exist (category G). All were recorded from both groups, although $E$. soleirolii and N. notha were more abundant and occurred more frequently in permanent watercourses.

Information regarding trophic preferences (for $\sim 70 \%$ of the taxa) and $\mathrm{pH}$ (for $\sim 75 \%$ of the taxa) was available for the majority of the taxa. Nevertheless, $48.5 \%$ of the taxa lacked information regarding their habitat preferences; $51.5 \%$ had no details regarding current velocity, and $38.6 \%$ lacked details regarding moisture preferences (Appendix A).

\section{Ecological guilds}

The majority of the taxa identified within temporary watercourses belonged to the low-profile guild (44.0\%) followed by the high-profile $(31.2 \%)$ and motile $(24.8 \%)$ guilds. Permanent sites were dominated by low-profile taxa $(35.4 \%)$; nevertheless, there was a higher percentage of high-profile and motile taxa (33.8\% and $30.8 \%$, respectively). Although there were no significant differences among the number of taxa assigned to each guild per group, it is clear that the low-profile guild dominated the relative abundance in both groups $(77.5 \%$ temporary and $75.8 \%$ permanent watercourses), followed by high-profile (12.3\% in both groups) and motile guilds (10.2\% temporary and $11.9 \%$ permanent watercourses). No strong Spearman rank correlations $(\rho>0.5$, $p<0.05)$ were observed between any ecological guilds' relative abundance and environmental variables. Significant correlations were recorded between low-profile and motile guilds and the SPI index, although these were not strong $(\rho=0.39$ and $\rho=-0.38$, respectively, $p<0.05$ ).

\section{Characteristic diatom taxa and their ecological preferences}

Indicator value analysis undertaken to identify diatom taxa that are characteristic of temporary or permanent watercourses 
demonstrated that Amphora copulata, Cocconeis placentula, Diploneis separanda, Encyonopsis subminuta, Fragilaria radians, Gomphonema olivaceum, Gomphonema truncatum, Halamphora veneta, Navicula radiosa, Navicula veneta, Sellaphora seminulum and Ulnaria acus were indicators of temporary watercourses, whereas Encyonema minutum, Eunotia minor, Fragilaria rumpens, Fragilaria cf. socia and Navicula rhynchocephala were characteristic of permanent watercourses (Table III). The taxa characteristic of temporary watercourses were also common in highly intermittent, waterlogged (wet subaerial - four taxa) and moist soils (moist subaerial-three taxa); only two taxa were considered aquatic, although data were not available for three taxa. Most taxa indicative of temporary waterbodies were indifferent to the current velocity (eight taxa; Appendix A). As for the $\mathrm{pH}$ preferences, five taxa were classified as alkaliphilous (class 4), four as neutrophilous and two as alkalibiontic, and there was no information available for D. separanda. Regarding the trophic preferences, five taxa were classified as eutraphentic, two as meso-eutraphentic and one as oligotraphentic (E. subminuta), and D. separanda and F. radians were not classified. Three of these taxa were not present in the Red List classification (Appendix A).

The five taxa indicative of permanent watercourses were also commonly present in non-permanent water bodies; they were largely indifferent regarding current velocity preferences. Three taxa lack information regarding moisture preferences, whereas E. minutum is strictly aerophilous and $N$. rhynchocephala is occasionally aerophilous. Their $\mathrm{pH}$ preferences were quite diverse, as E. minor is acidophilous, E. minutum and F.rumpens are neutrophilous and N. rhynchocephala is alkaliphilous. Data on trophic preferences were only available for $F$. rumpens (eutraphentic) and N. rhynchocephala (indifferent). Fragilaria cf. socia was not classified in the Red List (Appendix A). Because these were taxa characteristic of both types of watercourses, their ecological preferences are highlighted for the environmental variables that statistically separate temporary and permanent watercourses (Table IV). Taxa characteristic of temporary watercourses have a clear preference for sites with lower current velocity and higher conductivity and $\mathrm{pH}$

Table III. Indicator values for the characteristic taxa of temporary or permanent watercourses examined in this study

\begin{tabular}{|c|c|c|c|c|c|c|c|}
\hline \multirow[b]{2}{*}{ Code } & \multirow[b]{2}{*}{ Taxon name } & \multicolumn{3}{|c|}{ Temporary } & \multicolumn{3}{|c|}{ Permanent } \\
\hline & & $\mathbf{F}$ & $\mathbf{S}$ & IndVal & $\mathbf{F}$ & $\mathbf{S}$ & IndVal \\
\hline ACOP & $\begin{array}{l}\text { Amphora copulata (Kützing) Schoeman \& } \\
\text { R.E.M. Archibald } 1986\end{array}$ & 23 & 83 & 19 & 8 & 17 & 1 \\
\hline CPLA & Cocconeis placentula Ehrenberg 1838 & 10 & 99 & 10 & 2 & 1 & 0 \\
\hline DSEP & Diploneis separanda Lange-Bertalot 2004 & 31 & 92 & 28 & 8 & 8 & 1 \\
\hline ENMI & $\begin{array}{l}\text { Encyonema minutum (Hilse in Rabenhorst) } \\
\text { D.G. Mann } 1990\end{array}$ & 13 & 18 & 2 & 38 & 82 & 31 \\
\hline ESUM & $\begin{array}{l}\text { Encyonopsis subminuta Krammer \& E. } \\
\text { Reichardt } 1997\end{array}$ & 10 & 100 & 10 & 0 & 0 & 0 \\
\hline EMIN & Eunotia minor (Kützing) Grunow 1881 & 5 & 2 & 0 & 23 & 98 & 22 \\
\hline FRAD & $\begin{array}{l}\text { Fragilaria radians (Kützing) D.M. Williams \& } \\
\text { Round } 1987\end{array}$ & 13 & 100 & 13 & 0 & 0 & 0 \\
\hline FRUM & $\begin{array}{l}\text { Fragilaria rumpens (Kützing) G.W.F. Carlson } \\
1913\end{array}$ & 21 & 29 & 6 & 43 & 71 & 31 \\
\hline FSOC & $\begin{array}{l}\text { Fragilaria cf. socia (N.M. Wallace) Lange- } \\
\text { Bertalot } 1980\end{array}$ & 0 & 0 & 0 & 25 & 0 & 25 \\
\hline GOLI & $\begin{array}{l}\text { Gomphonema olivaceum (Hornemann) } \\
\text { Brébisson } 1838\end{array}$ & 13 & 100 & 13 & 0 & 0 & 0 \\
\hline GTRU & Gomphonema truncatum Ehrenberg 1832 & 18 & 89 & 16 & 4 & 11 & 0 \\
\hline HVEN & Halamphora veneta (Kützing) Levkov 2009 & 33 & 93 & 31 & 6 & 7 & 0 \\
\hline NRAD & Navicula radiosa Kützing 1844 & 18 & 90 & 16 & 8 & 10 & 1 \\
\hline NRHY & Navicula rhynchocephala Kützing 1844 & 5 & 16 & 1 & 21 & 84 & 17 \\
\hline NVEN & Navicula veneta Kützing 1844 & 67 & 72 & 48 & 42 & 28 & 12 \\
\hline SSEM & $\begin{array}{l}\text { Sellaphora seminulum (Grunow) D.G. Mann } \\
1989\end{array}$ & 3 & 81 & 29 & 23 & 19 & 4 \\
\hline UACU & Ulnaria acus (Kützing) Aboal 2003 & 18 & 100 & 18 & 0 & 0 & 0 \\
\hline
\end{tabular}

Monte Carlo random permutations tests were used to assess the significance of each taxon as a group-specific indicator $(p<0.05)$. Fidelity (F) and specificity (S) values are also presented. 
Table IV. Abundance-weighted averages (WA) and range for the 11 environmental variables that were significantly different between temporary and permanent watercourses

\begin{tabular}{|c|c|c|c|c|c|c|c|c|c|}
\hline & & ACOP & CPLA & DSEP & EMIN & ENMI & ESUM & FRAD & FRUM \\
\hline \multirow[t]{2}{*}{ Current velocity $\left(\mathrm{m} \mathrm{s}^{-1}\right)$} & WA & 0.12 & 0.02 & 0.27 & 0.44 & 0.53 & 0.88 & 0.87 & 0.67 \\
\hline & Range & $1-0.73$ & $0-0.64$ & $0-0.80$ & $0-0.85$ & $0-0.97$ & $0.61-1.18$ & $0.61-1.18$ & $0-1.41$ \\
\hline \multirow[t]{2}{*}{$\mathrm{T}\left({ }^{\circ} \mathrm{C}\right)$} & WA & 22.2 & 25.9 & 20 & 24.6 & 24.1 & 17.5 & 19.7 & 20.8 \\
\hline & Range & $13.0-29.4$ & $21.0-28.7$ & $9.4-28.7$ & $14.1-28.2$ & $13.0-32.6$ & $13.3-20.1$ & $13.3-20.1$ & $11.8-28.0$ \\
\hline \multirow[t]{2}{*}{ Conductivity $\left(\mathrm{mS} \mathrm{cm}^{-1}\right)$} & WA & 663 & 365 & 606 & 162 & 125 & 189 & 223 & 157 \\
\hline & Range & $109-860$ & $98-409$ & $98-1393$ & $55-428$ & $55-543$ & $124-230$ & $124-230$ & $55-637$ \\
\hline \multirow[t]{2}{*}{$\mathrm{pH}$} & WA & 8.0 & 6.9 & 7.3 & 6.4 & 6.9 & 6.9 & 6.8 & 7.1 \\
\hline & Range & $6.6-8.6$ & $6.7-8.2$ & $6.6-8.6$ & $5.7-8.2$ & $5.7-8.9$ & $6.3-7.7$ & $6.3-7.7$ & $6.3-8.5$ \\
\hline \multirow[t]{2}{*}{ DO $(\%)$} & WA & 109.9 & 79.5 & 78.4 & 83.7 & 80.9 & 74.8 & 84.6 & 77.9 \\
\hline & $\mathrm{Rz}$ & $38.3-128.6$ & $66.3-98.6$ & $42.9-128.6$ & $31.5-116.8$ & $31.5-148.2$ & $59.8-91.9$ & $59.8-91.9$ & $42.9-116.8$ \\
\hline \multirow[t]{2}{*}{ Alkalinity $\left(\mathrm{mg} \mathrm{L}^{-1}\right)$} & WA & 222 & 130 & 167 & 46 & 42 & 43 & 49 & 42 \\
\hline & Range & $28-274$ & $46-172$ & $31-386$ & $26-157$ & $25-225$ & $31-53$ & $31-53$ & $24-110$ \\
\hline \multirow[t]{2}{*}{ Calcium $\left(\mathrm{mg} \mathrm{L}^{-1}\right)$} & WA & 62.2 & 30.8 & 44.3 & 22.9 & 10.5 & 15.2 & 10.7 & 10.1 \\
\hline & Range & $8.0-107.0$ & $4.8-43.3$ & $4.8-144.0$ & $6.0-58.0$ & $4.6-87.0$ & $10.0-24.0$ & $10.0-24.0$ & $5.6-24.0$ \\
\hline \multirow[t]{2}{*}{ Chloride $\left(\mathrm{mg} \mathrm{L}^{-1}\right)$} & WA & 88.2 & 50.6 & 72.3 & 27.8 & 17.2 & 25.6 & 28.3 & 27.9 \\
\hline & Range & $16.4-148.9$ & $13.9-57.1$ & $13.9-163.8$ & $7.7-37.7$ & $5.0-99.3$ & $20.8-29.8$ & $20.8-29.8$ & $5.9-163.8$ \\
\hline \multirow[t]{2}{*}{ Hardness $\left(\mathrm{mg} \mathrm{L}^{-1}\right)$} & WA & 251 & 110 & 208 & 27 & 27 & 69 & 52 & 34 \\
\hline & Range & $10-312$ & $10-182$ & $10-528$ & $6-182$ & $10-242$ & $46-100$ & $46-100$ & $10-160$ \\
\hline \multirow[t]{2}{*}{ Magnesium $\left(\mathrm{mg} \mathrm{L}^{-1}\right)$} & WA & 20.9 & 8.2 & 25.5 & 3.8 & 5.8 & 7.5 & 5.9 & 5.9 \\
\hline & Range & $2.7-28.2$ & $2.9-23.8$ & $1.9-85.5$ & $0.7-23.8$ & $0.4-28.2$ & $4.4-9.7$ & $4.4-9.7$ & $0.5-25.2$ \\
\hline \multirow{2}{*}{ Sodium $\left(\mathrm{mg} \mathrm{L}^{-1}\right)$} & WA & 7.7 & 4.9 & 7 & 2.3 & 2.2 & 6 & 3.1 & 3.2 \\
\hline & Range & $0.7-11.8$ & $0.7-5.8$ & $0.7-15.8$ & $0.7-9.8$ & $0.7-9.8$ & $2.4-11.2$ & $2.4-11.2$ & $0.7-13.1$ \\
\hline
\end{tabular}

The taxa reflect a spectrum of taxa from temporary and permanent watercourses. The names of the taxa corresponding to the codes (in four letters) are provided in Table III.

(except for Encyonopsis minuta). Similar preferences were detected for alkalinity, chloride, hardness, magnesium and sodium, which were generally higher for taxa characteristic of temporary watercourses. When considering the percentage oxygen saturation, with the exception of A.copulata, there were no significant differences detected among the groups, probably because all sites were not subject to strong anthropogenic pressures.

\section{Diatom metrics and environmental variables}

The mean values, standard deviation, median and interquartile range for taxa richness $(S)$, Shannon index of diversity $\left(H^{\prime}\right)$, Pielou's evenness index $\left(J^{\prime}\right)$ and the SPI are presented in Table V. Results of regressions between environmental parameters that differed significantly between temporary and permanent watercourses and taxa richness $(S)$, Shannon index of diversity $\left(H^{\prime}\right)$, Pielou's evenness index $\left(J^{\prime}\right)$ or SPI are presented in Table VI. There was no evidence of multicollinearity, and no positive or negative serial correlations were recorded at $p=0.05$, except a slightly positive autocorrelation in evenness $\left(J^{\prime}\right)$. There were significant differences for taxa richness $(S)$ between temporary and permanent watercourses because of an interaction between average annual runoff and the qualitative variable (temporary/permanent). The qualitative variable (temporary or permanent) explained $47.3 \%$ of the variation of taxa richness, whereas oxygen explained $35.4 \%$ and calcium $17.3 \%$. No significant differences were recorded between watercourses for $H^{\prime}$ and $J^{\prime}$ with pH explaining $98.9 \%$ and $99.2 \%$ of their variation or for the SPI, where average annual runoff explained $44.1 \%$, alkalinity $21.6 \%$, current velocity $18.8 \%$ and oxygen $15.5 \%$ of the variance in the data.

\section{DISCUSSION AND CONCLUSIONS}

The environmental characterization of watercourses in the south of Portugal clearly differentiated temporary and permanent sites on the basis of catchment characteristics and climatological variables. Among the hydromorphological variables, only current velocity was statistically different between the two stream types, whereas other variables only differed slightly between the temporary and permanent waterbodies. The lack of significant hydromorphological differences reflects the characteristics of Mediterranean watercourses generally, independent of the hydrologic regime. It is important that further research is undertaken on headwater temporary watercourses, characterized by short distances to source and small catchment area, and especially their role in the supply, transport and fate of water resources and solutes (including pollutants; Barceló and Sabater, 2010). Temporary watercourses experience greater variation in annual precipitation (Lilleb $\varnothing$ et al., 2007). This fact, coupled with their smaller watersheds, 
Table IV. (Continued)

\begin{tabular}{|c|c|c|c|c|c|c|c|c|}
\hline FSOC & GOLI & GTRU & HVEN & NRAD & NRHY & NVEN & SSEM & UACU \\
\hline 0.27 & 0.28 & 0.12 & 0.23 & 0.41 & 0.57 & 0.35 & 0.4 & 0.35 \\
\hline $0.02-1.41$ & $0-1.19$ & $0-0.87$ & $0-1.06$ & $0-0.97$ & $0.17-0.97$ & $0-1.63$ & $0-1.63$ & $0-1.18$ \\
\hline $16.3-32.6$ & $17.2-20.1$ & $13.0-29.2$ & $11.8-28.7$ & $13.0-26.8$ & $11.8-29.2$ & $9.4-29.2$ & $9.4-29.4$ & $17.1-20.0$ \\
\hline 101 & 460 & 300 & 411 & 241 & 210 & 396 & 441 & 426 \\
\hline $69-200$ & $223-543$ & $78-411$ & $98-1361$ & $55-472$ & $65-616$ & $55-1393$ & $76-1361$ & $223-1348$ \\
\hline 72.8 & 77.3 & 84.2 & 83.8 & 76.3 & 82.3 & 74.0 & 74.8 & 74.3 \\
\hline $66.1-148.2$ & $75.3-91.9$ & $69.0-99.0$ & $67.5-103.7$ & $51.4-115.3$ & $31.5-106.5$ & $31.5-128.6$ & $31.5-121.0$ & $49.7-84.6$ \\
\hline 51 & 171 & 98 & 100 & 57 & 43 & 93 & 71 & 94 \\
\hline $24-56$ & $48-225$ & $36-174$ & $25-225$ & $28-174$ & $25-157$ & $25-386$ & $25-268$ & $46-270$ \\
\hline 8.9 & 63.3 & 15.4 & 26.9 & 11.5 & 14.3 & 27.7 & 19.9 & 28.1 \\
\hline $5.6-18.4$ & $10.0-87.0$ & $4.6-22.0$ & $4.8-87.0$ & $5.6-19$ & $5.6-58.0$ & $5.6-144.0$ & $4.6-92.0$ & $10.0-107.0$ \\
\hline 4.8 & 6.7 & 14.4 & 8.2 & 7.9 & 4.6 & 11 & 9 & 5.6 \\
\hline $0.7-7.1$ & $4.4-10.5$ & $0.4-28.2$ & $1.7-28.2$ & $1.0-28.2$ & $0.7-11.9$ & $0.7-85.5$ & $0.4-24.5$ & $2.7-10.5$ \\
\hline 1.3 & 1.8 & 3.4 & 4.2 & 3.4 & 4.3 & 4.9 & 4.7 & 3.4 \\
\hline $0.7-9.8$ & $1.1-3.7$ & $0.7-8.9$ & $0.7-13.1$ & $0.7-9.8$ & $0.7-13.1$ & $0.7-15.8$ & $0.7-13.1$ & $2.4-8.6$ \\
\hline
\end{tabular}

helps explain the high inter-annual and intra-annual variability of the flow regime and their unpredictability.

Water chemistry parameters and indicators of anthropogenic contamination did not differ between temporary and permanent watercourses. This reflects the sample design focussed on relatively unimpaired sites. Nevertheless, indicators of organic enrichment were more abundant in permanent watercourses (Table II) and reflect the greater catchment area and agricultural/pastoral practices (Hlúbiková et al., 2014). However, it was interesting to note that contrary to the findings of authors such as Moore et al. (2005) and Studinski et al. (2012), the percentage of riparian vegetation did not have a significant effect on stream temperature and may reflect the sclerophyllous and evergreen riparian vegetation typical of southern Portugal and the wider Mediterranean region (Gasith and Resh, 1999).
The low-profile guild dominated the relative abundance of both temporary and permanent watercourses, reflecting the frequent disturbance and low nutrient content. These environmental conditions favour small taxa that are able to persist in low-nutrient environments, withstand extreme flow events and recolonize sites rapidly. These results support observations of Berthon et al. (2011) and Hlúbiková et al. (2014), who reported a dominance of low-profile diatoms in nutrient-poor environments. Even though the temporary and permanent watercourses studied differed significantly with regard to a number of environmental parameters, such as watershed characteristics, climatological variables, current velocity and water chemistry, diatom guilds did not reflect these differences. In addition, light availability and shading did not appear to influence the diatom ecological guilds, probably because of the riparian vegetation associated with

Table V. Mean values, standard deviation, median and interquartile range for the taxa richness $(S)$, Shannon index of diversity $\left(H^{\prime}\right)$, Pielou's evenness index $\left(J^{\prime}\right)$ and Specific Pollution Sensitivity Index for the temporary and permanent watercourses examined in this study

\begin{tabular}{|c|c|c|c|c|c|c|}
\hline & \multicolumn{3}{|c|}{ Temporary } & \multicolumn{3}{|c|}{ Permanent } \\
\hline & Mean \pm SD & Median & Interquartile range & Mean \pm SD & Median & Interquartile range \\
\hline Taxa richness & $26.87 \pm 8.83$ & 28.00 & $19.00-33.00$ & $25.91 \pm 1.00$ & 23.00 & $19.00-33.00$ \\
\hline Shannon index of diversity $\left(H^{\prime}\right)$ & $2.72 \pm 0.91$ & 2.93 & $2.08-3.49$ & $2.64 \pm 0.85$ & 2.78 & $2.06-3.16$ \\
\hline Pielou's evenness index $\left(J^{\prime}\right)$ & $0.57 \pm 0.15$ & 0.60 & $0.48-0.70$ & $0.56 \pm 0.14$ & 0.58 & $0.50-0.65$ \\
\hline Specific Pollution Sensitivity Index & $15.93 \pm 1.86$ & 15.70 & $14.45-17.45$ & $16.76 \pm 1.99$ & 17.50 & $15.0-18.5$ \\
\hline
\end{tabular}




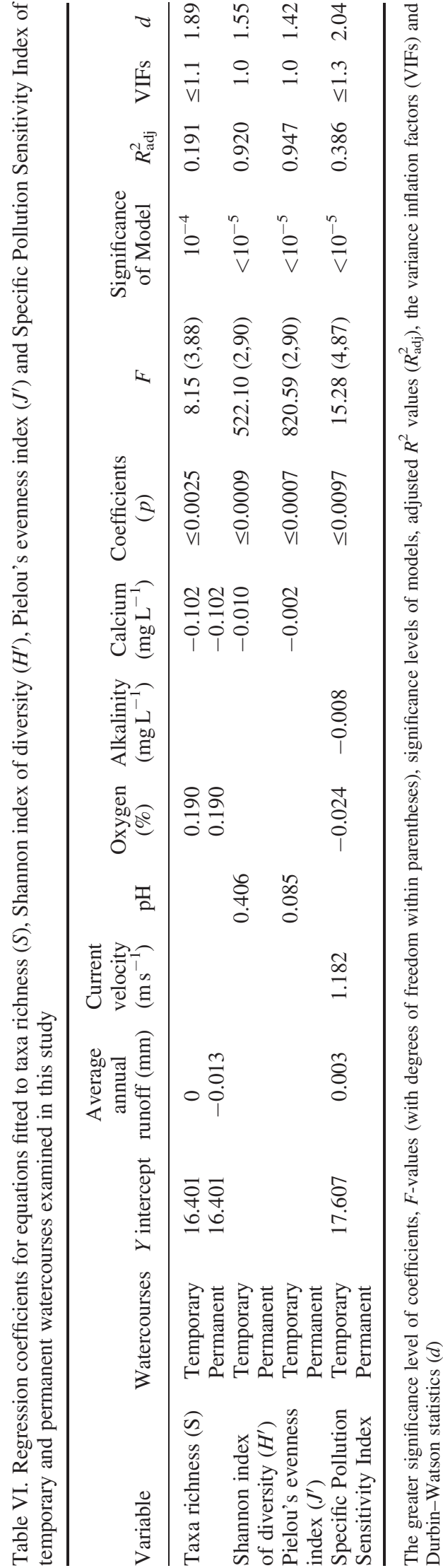

Mediterranean rivers. Therefore, nutrient content appears to be the primary main factor driving ecological guild abundance in the rivers examined. This is in marked contrast to Swedish low-acidity lakes, where grazing and light levels might play an important role in determining their distribution (Gottschalk and Kahlert, 2012). In addition, current velocity did not appear to influence ecological guild abundance, suggesting that under nutrient-deficient conditions, flow plays a secondary role (Larson and Passy, 2012).

Even though only a few taxa were classified as threatened, a number of other taxa had conservation designations independently of being temporary or permanent water specialists, highlighting the need to manage and conserve 'unimpacted' watercourses, independently of their hydrological regime. Additionally, $\sim 30 \%$ of the identified taxa were not recorded on the Red List of Lange-Bertalot and Steindorf (1996), and little or no information was available regarding the ecological preferences of several taxa indicative of both permanent and temporary watercourses. This may also reflect the fact that some taxa have only recently been described, such as Pseudostaurosira alvareziae or Geissleria lusitanica (Cejudo-Figueiras et al., 2011; Novais et al., 2013).

The importance of temporary watercourses for the maintenance of diatom biodiversity has been clearly demonstrated by the results of this study, as the variation in diatom taxa richness (higher in temporary watercourses) was directly linked with the average annual runoff. Diatom species richness increased with natural hydrological disturbance (drying), in accordance with the intermediate disturbance theories. Williams et al. (2003) also reported an increase in aquatic diversity in association with disturbance (physical habitat complexity), although their field observations suggested that seasonality reduced the richness of some ponds compared with species-rich river sites. Further studies are therefore required to explore the wider applicability of the results reported, as the relationship between species richness and connectivity is determined by a series of complex factors, with species richness maxima for different faunal and floral elements occurring at different positions along hydrological connectivity and permanence gradients (Ward et al., 2002).

Further studies centred on phytobenthos in temporary Mediterranean watercourses are required, not only for biodiversity conservation purposes but also for the determination of diatom richness along the riverine connectivity gradient and to provide a greater understanding of physiological aspects of diatom adaptation to drought.

\section{ACKNOWLEDGEMENTS}

This project was supported by Fundação para a Ciência e a Tecnologia—Portugal (PhD grant SFRH/BD/21625/2005), by the Fonds National de la Recherche du Luxembourg 
(grant AFR, PHD-09-120) and by the Public Research Centre-Gabriel Lippmann (Luxembourg). The National Water Institute is thanked for the data on watershed characteristics and the climate. Vanessa Peardon is gratefully acknowledged for English grammar revisions of the manuscript.

\section{REFERENCES}

APHA. 1995. Standard Methods for the Examination of Water and Wastewater, 19 Ed. American Public Health Association, American Water Works Association, and Water Pollution Control Federation: Washington, DC.

Barceló D, Sabater S. 2010. Water quality and assessment under scarcity: prospects and challenges in Mediterranean watersheds. Journal of Hydrology 383: 1-4. DOI: 10.1016/j.jhydrol.2010.01.010

Berthon V, Bouchez A, Rimet F. 2011. Using diatom life-forms and ecological guilds to assess organic pollution and trophic level in rivers: a case study of rivers in south-eastern France. Hydrobiologia 673: 259-271. DOI: $10.1007 / \mathrm{s} 10750-011-0786-1$

Blanco S, Ector L, Huck V, Monnier O, Cauchie HM, Hoffmann L, Bécares E. 2008. Diatom assemblages and water quality assessment in the Duero basin (NW Spain). Belgian Journal of Botany 141: 39-50. DOI: 10.2307/ 20794650

Cejudo-Figueiras C, Morales EA, Wetzel CE, Blanco S, Hoffmann L, Ector L. 2011. Analysis of the type of Fragilaria construens var. subsalina (Bacillariophyceae) and description of two morphologically related taxa from Europe and the United States. Phycologia 50: 67-77. DOI: $10.2216 / 09-40.1$

Cemagref. 1982. Etude des Méthodes Biologiques d'Appréciation Quantitative de la Qualité des Eaux. Ministère de l'Agriculture, Cemagref, Division Qualité des Eaux, Pêche et Pisciculture: Lyon, 218 pp.

Delgado C, Pardo I, García L. 2012. Diatom communities as indicators of ecological status in Mediterranean temporary streams (Balearic Islands, Spain). Ecological Indicators 15: 131-139. DOI: 10.1016/j. ecolind.2011.09.037

Denys L. 1991. A check-list of the diatoms in the Holocene deposits of the western Belgian coastal plain with a survey of their apparent ecological requirements, vol. I. Professional Paper. Geological Survey of Belgium, 1991/02 (246). Geologische Dienst van België: Brussels, 41 pp.

Directive 2000/60/EC of the European Parliament and of the Council of 23 October 2000 establishing a framework for community action in the field of water policy. Official Journal of the European Communities L327: 1-72.

Dodkins I, Aguiar F, Rivaes R, Albuquerque A, Rodríguez-González P, Ferreira MT. 2012. Measuring ecological change of aquatic macrophytes in Mediterranean rivers. Limnologica 42: 95-107.

Dufrêne M, Legendre P. 1997. Species assemblages and indicator species: the need for a flexible asymmetrical approach. Ecological Monographs 67: $345-366$.

European Committee for Standardization. 2003. Water Quality-Guidance Standard for the Routine Sampling and Pretreatment of Benthic Diatoms from Rivers. European Standard EN 13946. European Committee for Standardization: Brussels, 14 pp.

Feio MJ, Coimbra CN, Graça MAS, Nichols SJ, Norris RH. 2010. The influence of extreme climatic events and human disturbance on macroinvertebrate community patterns of a Mediterranean stream over $15 \mathrm{y}$. Journal of the North American Benthological Society 29: 1397-1409. DOI: $10.1899 / 09-158.1$

Gasith A, Resh V. 1999. Streams in Mediterranean climate regions: abiotic influences and biotic responses to predictable seasonal events. Annual Review of Ecology and Systematics 30: 51-81. DOI: 10.1146/annurev. ecolsys.30.1.51
Giorgi F, Lionello P. 2008. Climate change projections for the Mediterranean region. Global and Planetary Change 63: 90-104. DOI: 10.1016/j. gloplacha.2007.09.005

Gomà J, Rimet F, Cambra J, Hoffmann L, Ector L. 2005. Diatom communities and water quality assessment in mountain rivers of the upper Segre basin (La Cerdanya, Oriental Pyrenees). Hydrobiologia 551: 219-225. DOI: $10.1007 / \mathrm{s} 10750-005-4462-1$

Gottschalk S, Kahlert M. 2012. Shifts in taxonomical and guild composition of littoral diatom assemblages along environmental gradients. Hydrobiologia 694: 41-56. DOI: 10.1007/s10750-012-1128-7

Hlúbiková D, Novais MH, Dohet A, Hoffmann L, Ector L. 2014. Effect of riparian vegetation on diatom assemblages in headwater streams under different land uses. Science of the Total Environment 475: 234-247. DOI: 10.1016/j.scitotenv.2013.06.004

INAG. 2008a. Tipologia de rios em Portugal Continental no Âmbito da Implementação da Directiva Quadro da Água. I - Caracterização abiótica. Ministério do Ambiente, do Ordenamento do Território e do Desenvolvimento Regional. Instituto da Água, I.P.: Lisboa, 32 pp.

INAG. 2008b. Manual para a Avaliação Biológica da Qualidade da Agua em Sistemas Fluviais Segundo a Directiva-Quadro da Água-Protocolo de Amostragem e Análise para o Fitobentos-Diatomáceas. Ministério do Ambiente, do Ordenamento do Território e do Desenvolvimento Regional. Instituto da Água, I. P.: Lisboa, 35 pp.

INAG. 2009. Critérios para a classificação do estado das massas de água superficiais-rios e albufeiras. Ministério do Ambiente, do Ordenamento do Território e do Desenvolvimento Regional. Instituto da Água, I. P.: Lisboa, $71 \mathrm{pp}$

IPCC. 2014. Summary for policymakers. In Climate Change 2014: Impacts, Adaptation, and Vulnerability. Contribution of Working Group II to the Fifth Assessment Report of the Intergovernmental Panel on Climate Change, Field C, Barros V, Mach K, Mastrandrea M (coordinating lead authors). Cambridge University Press: Cambridge and New York, NY; 1-44.

Krammer K, Lange-Bertalot H. 1986. Bacillariophyceae 1. Teil: Naviculaceae. In Süsswasserflora von Mitteleuropa, vol. 2/1, Ettl H, Gärtner G, Gerloff J, Heynig H, Mollenhauer D (eds). Gustav Fischer Verlag: Stuttgart; $1-876$.

Krammer K, Lange-Bertalot H. 1988. Bacillariophyceae 2. Teil: Bacillariaceae, Epithemiaceae, Surirellaceae. In Süsswasserflora von Mitteleuropa, vol. 2/2, Ettl H, Gärtner G, Gerloff J, Heynig H, Mollenhauer D (eds). Gustav Fischer Verlag: Stuttgart; 1-596.

Krammer K, Lange-Bertalot H. 1991a. Bacillariophyceae 3. Teil: Centrales, Fragilariaceae, Eunotiaceae. In Süsswasserflora von Mitteleuropa, vol. 2/ 3, Ettl H, Gärtner G, Gerloff J, Heynig H, Mollenhauer D (eds). Gustav Fischer Verlag: Stuttgart; 1-576.

Krammer K, Lange-Bertalot H. 1991b. Bacillariophyceae 4. Teil: Achnanthaceae. Kritische Ergänzungen zu Navicula (Lineolatae) und Gomphonema. Gesamtliteraturverzeichnis Teil 1-4. In Süsswasserflora von Mitteleuropa, vol. 2/4, Ettl H, Gärtner G, Gerloff J, Heynig H, Mollenhauer D (eds). Gustav Fischer Verlag: Stuttgart; 1-437.

Lange-Bertalot H, Steindorf A. 1996. Rote Liste der limnischen Kieselalgen (Bacillariophyceae). Schriftenreihe für Vegetationskunde 28: 633-677.

Larned ST, Datry T, Arscott DB, Tockner K. 2010. Emerging concepts in temporary-river ecology. Freshwater Biology 55: 717-738. DOI: $10.1111 / \mathrm{j} .1365-2427.2009 .02322 . x$

Larson CA, Passy S. 2012. Taxonomic and functional composition of the algal benthos exhibits similar successional trends in response to nutrient supply and current velocity. FEMS Microbiology Ecology 80: 352-362. DOI: $10.1111 / \mathrm{j} .1574-6941.2012 .01302 . x$

Lecointe C, Coste M, Prygiel J. 1993. "Omnidia": software for taxonomy, calculation of diatom indices and inventories management. Hydrobiologia 269-270: 509-513.

Lillebø AI, Morais M, Guilherme P, Fonseca R, Serafim A, Neves R. 2007. Nutrient dynamics in Mediterranean temporary streams: a case study in 
Pardiela catchment (Degebe River, Portugal). Limnologica 37: 337-348. DOI: 10.1016/j.limno.2007.05.002

Martín G, Toja J, Sala SE, Fernández MR, Reyes I, Casco MA. 2010. Application of diatom biotic indices in the Guadalquivir River Basin, a Mediterranean basin. Which one is the most appropriate? Environmental Monitoring and Assessment 170: 519-534. DOI: 10.1007/s10661-0091254-5

Moore RD, Spittlehouse DL, Story A. 2005. Riparian microclimate and stream temperature response to forest harvesting: a review. Journal of the American Water Resources Association 41: 813-834.

Morais M, Pinto P, Guilherme P, Rosado J, Antunes I. 2004. Assessment of temporary streams: the robustness of metric and multimetric indices under different hydrological conditions. Hydrobiologia 516: 229-249. DOI: 10.1007/978-94-007-0993-5_14

Novais MH, Blanco S, Delgado C, Morais M, Hoffmann L, Ector L. 2012. Ecological assessment of Portuguese reservoirs based on littoral epilithic diatoms. Hydrobiologia 695: 265-279. DOI: 10.1007/s10750-012-1197-7

Novais MH, Wetzel CE, Van de Vijver B, Morais MM, Hoffmann L, Ector L. 2013. New species and combinations in the genus Geissleria (Bacillariophyceae). Cryptogamie Algologie 34: 117-148.

Passy SI. 2007. Diatom ecological guilds display distinct and predictable behavior along nutrient and disturbance gradients in running waters. Aquatic Botany 86: 171-178. DOI: 10.1016/j.aquabot.2006.09.018

REFCOND. 2003. Guidance on establishing reference conditions and ecological status boundaries for inland surface waters. Working Group 2.3. EU Common Implementation Strategy (CIS) for the Water Framework Directive, $93 \mathrm{pp}$
Rosado J, Morais M, Serafim A, Pedro A, Silva H, Potes M, Brito D, Salgado R, Neves R, Lillebø A, Chambel A, Pires V, Pinto Gomes C, Pinto P. 2012. Key factors in the management and conservation of temporary Mediterranean streams: a case study of the Pardiela River, Southern Portugal. In River Conservation and Management, Boon PJ, Raven PJ (eds). John Wiley \& Sons, Ltd: Chichester; 271-281.

Studinski JM, Hartman KJ, Niles JM, Keyser P. 2012. The effects of riparian forest disturbance on stream temperature, sedimentation, and morphology. Hydrobiologia 686: 107-117. DOI: 10.1007/s10750-012-1002-7

Tockner K, Stanford JA. 2002. Riverine floodplains: present state and future trends. Environmental Conservation 29: 308-330. DOI: 10.1017/ S037689290200022X

Tooth S. 2000. Process, form and change in dryland rivers: a review of recent research. Earth-Science Reviews 51: 67-107. DOI: 10.1016/S00128252(00)00014-3

Ury HK. 1976. A comparison of four procedures for multiple comparisons among means (pairwise contrasts) for arbitrary sample sizes. Technometrics 18: 89-97. DOI: 10.1080/00401706.1976.10489405

Van Dam H, Mertens A, Sinkeldam J. 1994. A coded checklist and ecological indicator values of freshwater diatoms from The Netherlands. Netherlands Journal of Aquatic Ecology 28: 117-133.

Ward JV, Tockner K, Arscott DB, Claret C. 2002. Riverine landscape diversity. Freshwater Biology 47: 517-539.

Williams P, Whitfield M, Biggs J, Bray S, Fox G, Nicolet P, Sear D. 2003. Comparative biodiversity of rivers, streams, ditches and ponds in an agricultural landscape in Southern England. Biological Conservation 115: 329-341. 


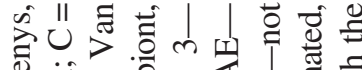
苂

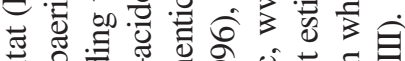

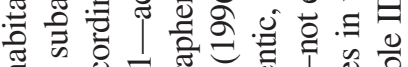
ख II I $>$ 它

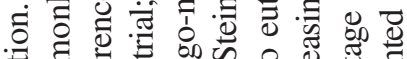

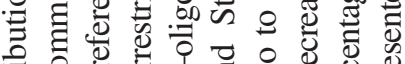

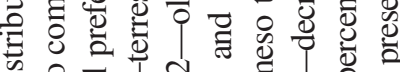

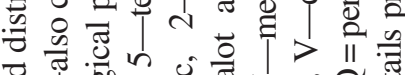

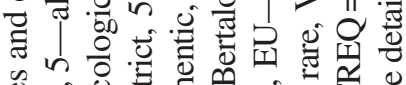

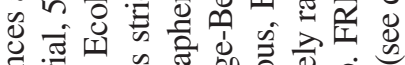

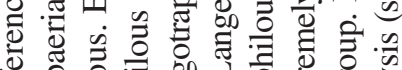

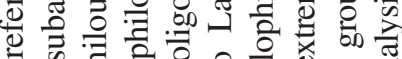

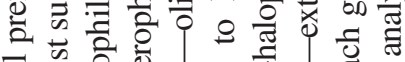
न

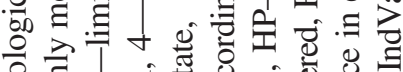

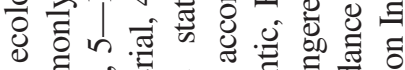

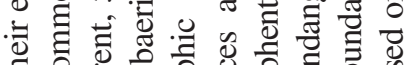

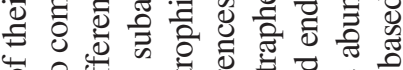

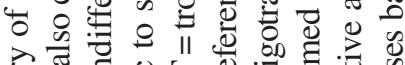

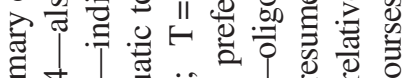

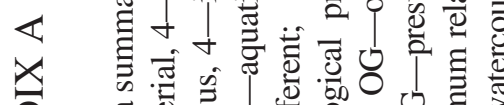

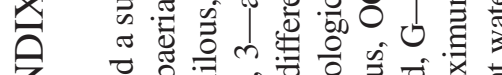

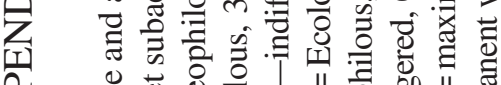

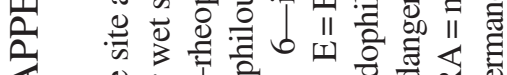

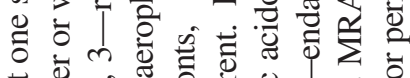

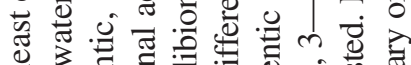
उ 3 등

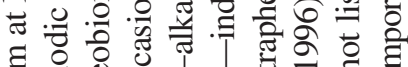

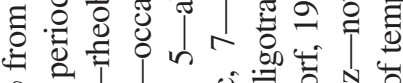
ㅇ.ヨda

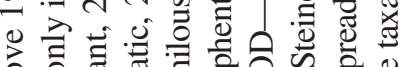

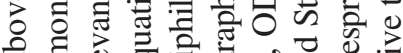

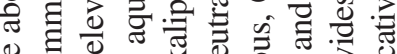

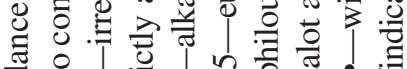

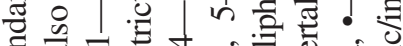

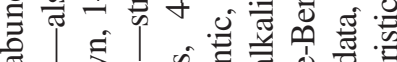
on o 约

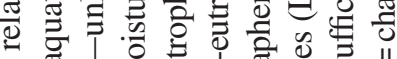
I0 E

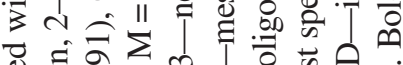

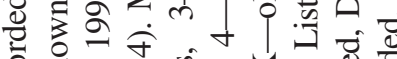
을

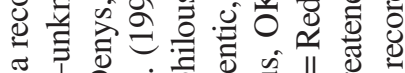
苋过它 पे

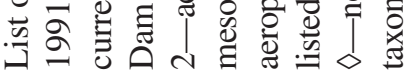

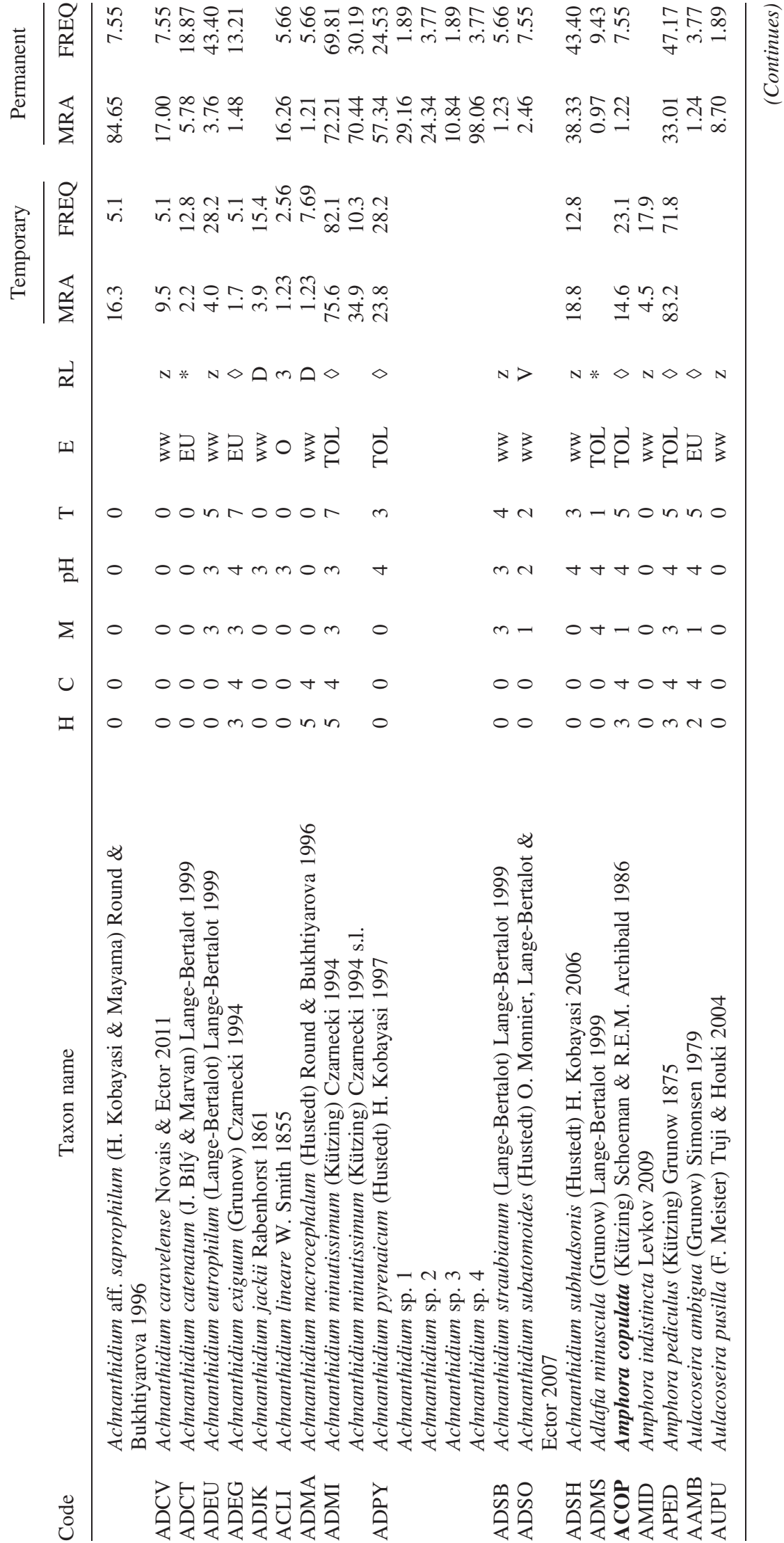




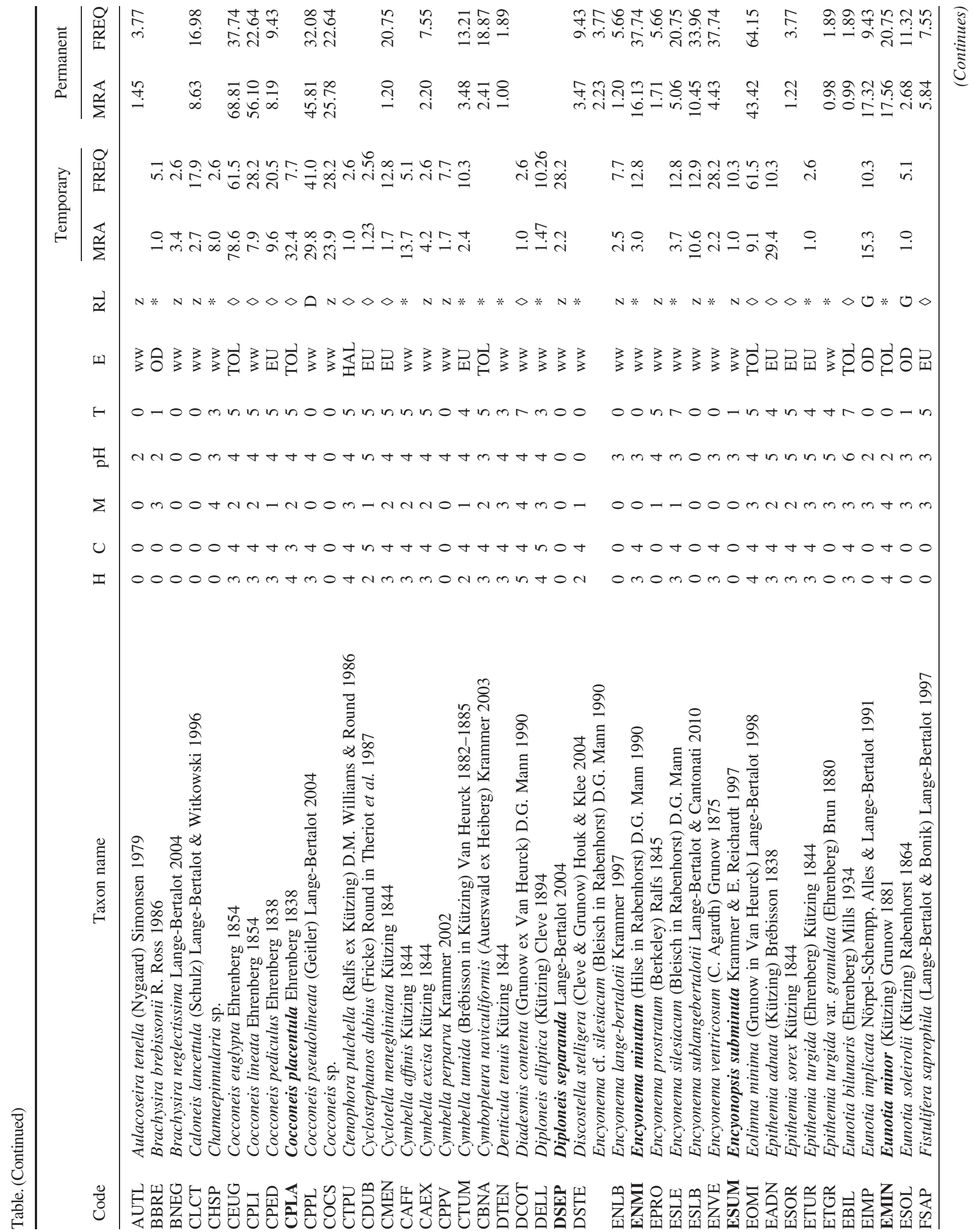




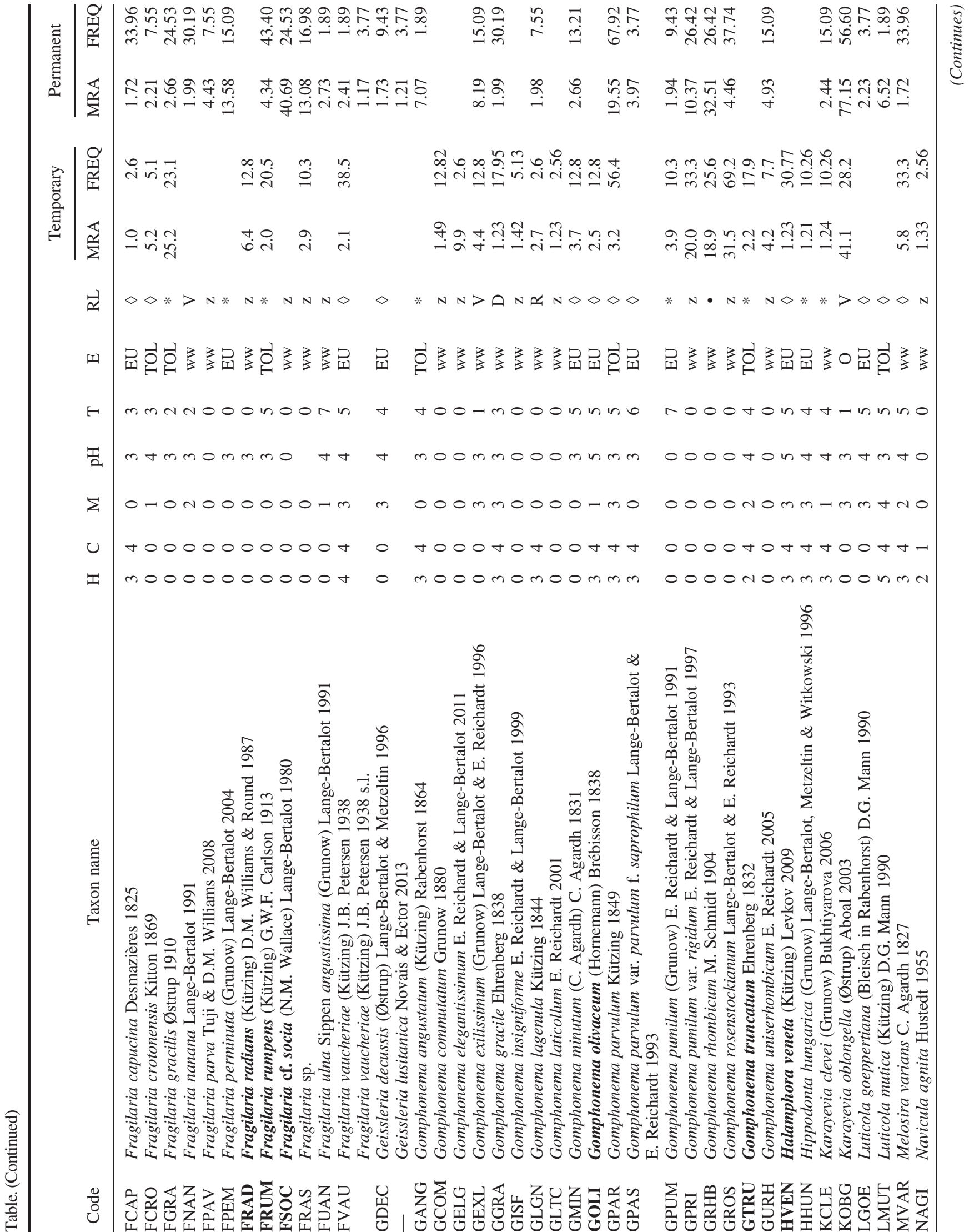




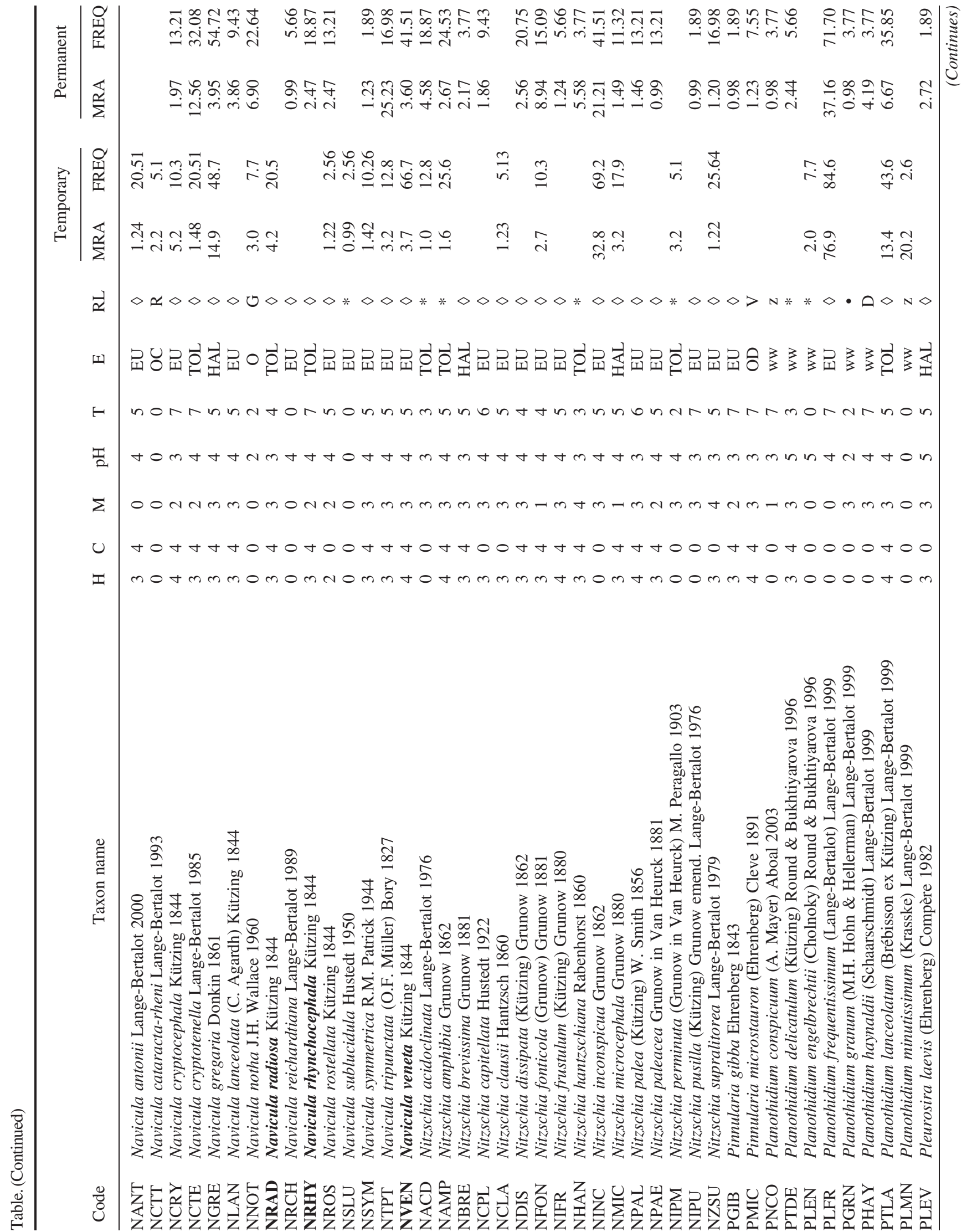




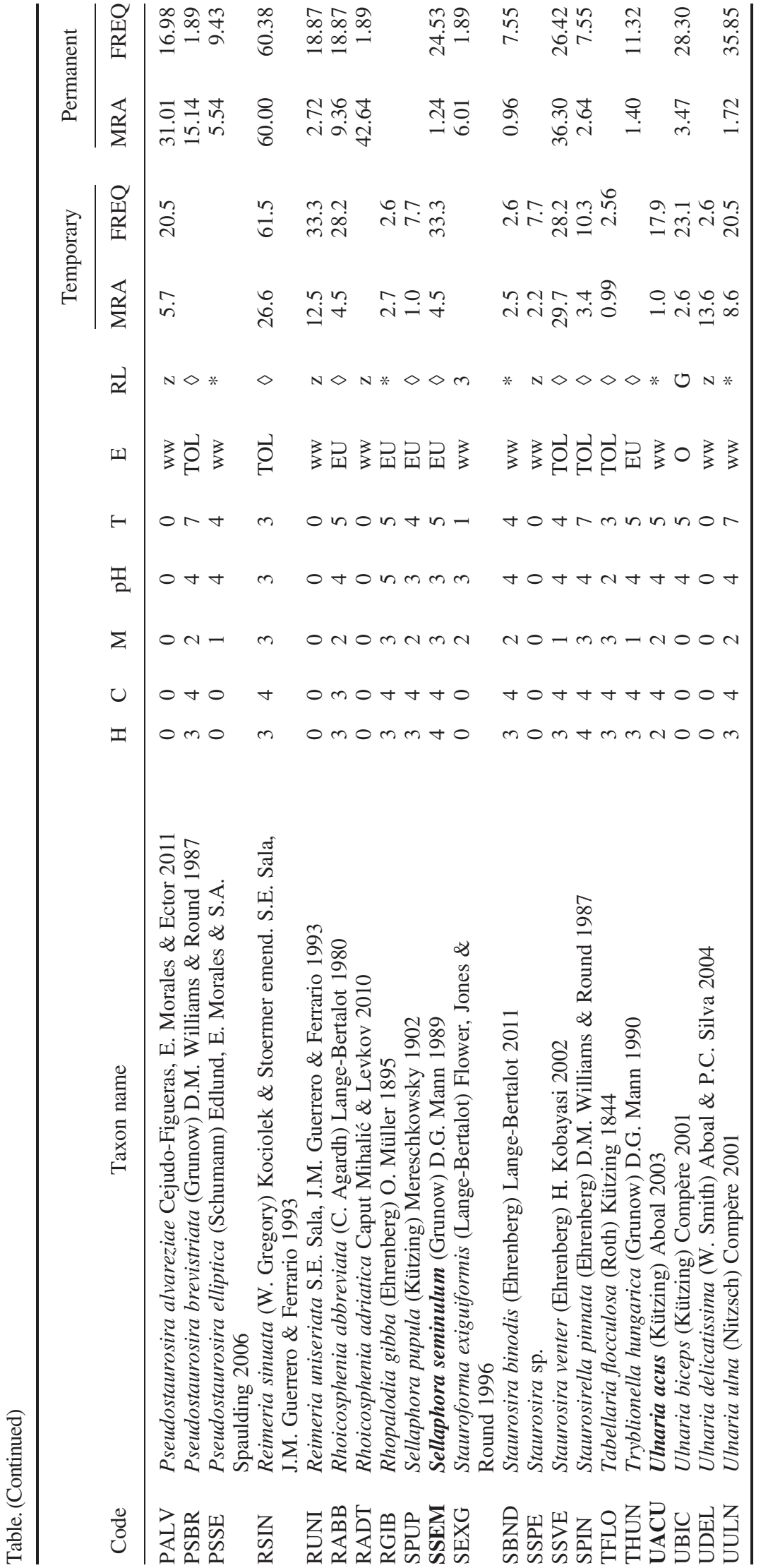

